\title{
The Prevalence of Chronic Diseases and Drug Use Among Geriatric Cases in Ardesen County of Rize Province
}

\author{
Didem SARIMEHMET ${ }^{1}$, Sevilay HINTISTAN² \\ ${ }^{1}$ Karadeniz Technical University, School of Health Sciences Nursing, Trabzon, Turkey \\ ${ }^{2}$ Karadeniz Technical University, Institute of Health Sciences, Internal Diseases Nursing, Trabzon, Turkey
}

\section{ABSTRACT}

Objective: This study aimed to evaluate the prevalence of chronic diseases and drug use among geriatric cases in Ardesen County of Rize Province.

Methods: A cross-sectional and descriptive correlational study including 482 elderly was conducted between March and June 2014. Data were collected using the personal information form via face-to-face interviews. All data were analyzed as percentages using the chi-square test.

Results: In this study, $97.9 \%$ of the elderly had chronic diseases and $52.9 \%$ were in the 65-74-year age group. The most frequent chronic diseases included those of the cardiovascular system (74.3\%). In addition, $49 \%$ of the group used three or four medications daily, and $99.2 \%$ took their medications orally. However, these medications caused gastrointestinal problems for $24.3 \%$ of the subjects. For $44.6 \%$ of the elderly, the most challenging aspect regarding their medications was forgetting to take them. Sex, age, profession, monthly income level, and social security status affected the duration of the chronic diseases of the elderly, whereas age, marital status, educational level, profession, social security coverage, and the people with whom they lived affected the number of medications used daily by this group $(\mathrm{p}<0.05)$.

Conclusion: Preventive measures should focus on reducing risk factors related to the development of chronic diseases and the drugs used to treat them.

Keywords: Chronic disease, drug use, aged, prevalence

\section{Introduction}

In 2015 , the elderly population comprised $8.5 \%$ of the total population of the world, and it continues to increase (1). The World Health Organization defines "elderly" as individuals who are aged $\geq 65$ years (2). In 2015, the elderly population of Turkey was 6,495,239, i.e., 8.2\% of the total population. The Turkish Statistical Institute reported that the lifespan in 2015 for females at birth was 80.7 years and for males was 75.3 years, whereas by 2023 , it would be $10.2 \%$ for females and males. These estimates indicate that the number of elderly will increase, and Turkey will have a very aged population (1).

As a person ages, the immune system weakens, thereby increasing one's vulnerability to chronic diseases (3). The World Health Organization estimates that 60\% (38 million) of deaths worldwide occur because of chronic diseases. Cardiovascular system (CVS) diseases, cancers, chronic respiratory tract diseases, and diabetes rank in the first place as causes of death (2). Chronic diseases afflict 422,000 people in Turkey and cause nearly $86 \%$ of deaths. In Turkey, the most common chronic diseases include CVS diseases (40.3\%), cancer (20.0\%), respiratory system diseases (11.1\%), and endocrine system diseases $(5.0 \%)(4)$.

Studies indicate that 70\%-90\% of elderly suffer from one or more chronic diseases (4-6). Ninety percent of individuals aged $\geq 65$ years have one chronic disease, $35 \%$ have two, $23 \%$ have three, and $15 \%$ have four (7). Individuals with

Cite this article as: Sarımehmet D, Hintistan S. The Prevalence of Chronic Diseases and Drug Use Among Geriatric Cases in Ardesen County of Rize Province. Bezmialem Science 2017; 5: 93-100.

$\begin{array}{lrl}\text { Address for Correspondence: Sevilay HiNTiSTAN; Karadeniz Technical University, Institue of Health Sciences, Internal } & \text { Received } & : 03.03 .2016 \\ \text { Diseases Nursing, Trabzon, Turkey E-mail: sevilayhindistan@gmail.com } & \text { Accepted } & : 18.07 .2016 \\ \text { OCopyright } 2017 \text { by Bezmialem Vakif University - Available online at www.bezmialemscience.org } & \end{array}$ 
more than one chronic disease can experience dysfunctions in sensory abilities and social skills, which may later require special care and rehabilitation $(3,5)$. Seventy-five percent of healthcare expenses of the world can be attributed to chronic diseases, with expenses approaching nearly one trillion dollars. These expenses represent an increasing burden, which threatens the healthcare systems of many nations $(2,8)$.

As stated earlier, aging process and onset of chronic diseases may lead to long-term and multiple medication use (9-11). In a study conducted in the United States of America-Mexico border region with subjects having an average age of 71.4 years, $72.4 \%$ of the subjects used five or more drugs, whereas $46.2 \%$ had a risk for drug-drug interactions (12). In the study with 3,005 subjects, Qato et al. (13) found that $29 \%$ of subjects aged $75-85$ years used at least five or more medications, $81 \%$ used at least one prescription drug, and $46 \%$ using prescription drugs also took unprescribed medications (13). In Turkey, the most commonly used drugs among the elderly were CVS medications (26.7\%), analgesics and nonsteroid antiinflammatory medications $(20.8 \%)$, gastrointestinal system (GIS) medications (12\%), and endocrine system medications (10.6\%) (4).

Multiple drug use; drug interactions; changes in drug absorption, metabolism, and elimination; and drug adverse effects owing to cognitive problems such as forgetfulness, are two to three times more likely to occur among the elderly population compared with the young population (9-10). In addition, multiple drug use (polypharmacy) increases the risk for numerous negative health consequences in the elderly. Specifically, the burden of taking multiple medications has been associated with greater healthcare expenses and an increased risk for adverse drug events, drug interactions, medication nonadherence, reduced functional capacity, and multiple geriatric syndromes $(6,9)$. Furthermore, medication noncompliance varies between $21 \%$ and $55 \%$ among the elderly and occurs more often among those who take more than three medications, who have more than one prescription, and who live alone $(10,14,15)$. Therefore, the elderly who have chronic diseases and use multiple drugs to manage their diseases require support for their treatment, care needs, and monitoring of medications (16).

To our knowledge, this is the first study in Turkey that aimed to evaluate the prevalence of chronic diseases and drug use among the elderly population aged $\geq 65$ years. Individuals who chose to participate were registered at the Family Medicine Unit in Ardesen County of Rize Province, Turkey.

\section{Methods}

\section{Design}

This was a cross-sectional and descriptive correlational study.

\section{Subjects and Setting}

This study was conducted between March and June 2014 with individuals aged $\geq 65$ years who were registered at the in the Eastern Black Sea region of Turkey. The study subjects were recruited using the registration forms of the Family Medicine Unit.

The study population comprised 515 elderly subjects aged $\geq 65$ years. No sampling was performed, and the whole population was targeted. However, the study was completed with 482 subjects because 12 had moved elsewhere owing to health problems, 15 were unable to answer the survey questions, and six refused to participate in the study. The participation rate was $93.5 \%$.

The inclusion criteria were subjects aged $\geq 65$ years; those able to speak Turkish; those who could orally communicate; those who could demonstrate orientation to persons, place, and time; and those who could confirm their willingness to participate in the study.

The exclusion criteria were subjects aged $\leq 65$ years; those who could not speak Turkish; those who could not orally communicate; those who could not demonstrate orientation to persons, place, and time; and those who could not confirm their willingness to participate in the study.

\section{Data Collection and Tools}

Data for the study were collected using the personal information form via face-to-face interviews.

\section{Personal Information Form}

The personal information form was designed by the study researchers after reviewing relevant literature. The form comprised 17 questions related to sociodemographic characteristics (age, sex, marital status, education level, etc.), chronic disease (diagnosis and duration of the disease, etc.), and medications (number of medications used daily, route of drug administration, etc.).

\section{Procedure}

After the subjects received a detailed explanation regarding the purpose of the study, the researchers completed the personal information form during face-to-face interviews. The form was administered in two ways. For 376 subjects aged $\geq 65$ years who could visit the Family Medicine Unit, the researchers conducted face-to-face interviews in a private room to complete the form. Furthermore, for 106 subjects who could not visit the unit during the data collection phase, the researchers conducted the interviews during home visits. Questions in the personal information form were read by researchers to the elderly, and the answers received were recorded. Completion of the form took approximately $30 \mathrm{~min}$.

\section{Statistical Analysis}

All analyses were conducted using the Statistical Package for the Social Sciences for Windows version 21.0 (IBM Corporation, Somers, NY, USA). Numbers, percentages, and chisquare test were used for data analyses. Results with $\mathrm{p}$ values of $<0.05$ were considered to be significant, and the confidence interval was set at $95 \%$. 


\section{Ethical Considerations}

The study was approved by the Karadeniz Technical University Faculty of Medicine Ethics Council (2014/38), and official permission was obtained from the Rize Public Health Directorate of the Turkish Republic. All the subjects were informed regarding the aims and procedures of the study, and they gave written consent. The study conformed to the principles of the Declaration of Helsinki.

\section{Results}

The study results revealed that $53.1 \%$ of subjects were females, $52.9 \%$ belonged to the $65-74-$ year age group, $52.3 \%$ were married, $41.1 \%$ graduated from primary schools, $73.7 \%$ were retired, $50 \%$ had an income equal to expenses, $47.1 \%$ belonged to the state retirement fund for civil servants, and $39.4 \%$ lived with other family members.

This study also found that $97.9 \%$ of the subjects had chronic diseases, with $74.3 \%$ having CVS diseases, $40.7 \%$ having endocrine system diseases, $35.1 \%$ having musculoskeletal disorders, $51.1 \%$ having a chronic disease for $>16$ years, and $74.5 \%$ experiencing difficulties in performing activities of daily living (Table 1 ).

Moreover, the results revealed that nearly half of the study subjects (49\%) used 3-4 medications on a daily basis. Nearly all of the subjects (99.2\%) took medications orally, and $39.8 \%$ of them had health complaints owing to the drugs they used. GIS symptoms accounted for $24.3 \%$ of the total complaints. However, subjects stated that forgetting to take their medication was their most challenging aspect regarding medications (44.6\%; Table 2).

Our study found statistically significant differences between the duration of chronic diseases and sex, age, profession, monthly income level, and social security coverage $(\mathrm{p}<0.05$; Table 3).

Furthermore, statistically significant differences existed among the number of drugs used on a daily basis, age, marital status, educational level, profession, social security coverage, and the people with whom the subjects lived $(\mathrm{p}<0.05$; Table 4).

\section{Discussion}

Aging is an inevitable process and is generally accompanied by chronic diseases. Corrao et al. (17) found a prevalence of chronic disease in 55\%-98\% of people aged $>65$ years, and $97.9 \%$ of the elderly had chronic diseases. The current study revealed that chronic diseases were observed more often in low- and middle-income countries (2), and the elderly living in rural areas were more prone to developing chronic diseases (18). The elderly also tend to be less healthy and exhibit a higher prevalence of diseases with comorbidities and complications.

\begin{tabular}{|c|c|c|}
\hline Chronic disease characteristics & $\mathbf{n}$ & $\%$ \\
\hline \multicolumn{3}{|l|}{ Presence of chronic disease } \\
\hline Yes & 472 & 97.9 \\
\hline No & 10 & 2.1 \\
\hline \multicolumn{3}{|l|}{ Chronic diseases* $(n=472)$} \\
\hline Cardiovascular & 358 & 74.3 \\
\hline Endocrine & 196 & 40.7 \\
\hline Musculoskeletal & 169 & 35.1 \\
\hline Urinary & 127 & 26.3 \\
\hline Gastrointestinal & 121 & 25.1 \\
\hline Respiratory & 116 & 24.1 \\
\hline Cerebrovascular & 62 & 12.9 \\
\hline Hematologic & 57 & 11.8 \\
\hline Oncologic & 54 & 11.2 \\
\hline Skin & 54 & 11.2 \\
\hline \multicolumn{3}{|l|}{ Duration of the disease } \\
\hline $1-5$ years & 34 & 7.2 \\
\hline 6-10 years & 73 & 15.5 \\
\hline $11-15$ years & 124 & 26.3 \\
\hline$\geq 16$ years & 241 & 51.1 \\
\hline \multicolumn{3}{|l|}{ Difficulties owing to chronic disease* $(n=472)$} \\
\hline Difficulties in performing daily activities** & 359 & 74.5 \\
\hline Being a burden on others & 162 & 33.6 \\
\hline Difficulties in maintaining family-profession roles & 73 & 15.2 \\
\hline \multicolumn{3}{|c|}{$\begin{array}{l}\text { * } n \text { increased with more than one answer. } \\
\text { **Daily activities included cooking, bathing, dressing, climbing } \\
\text { up and down stairs, cutting nails, shopping, transportation, and } \\
\text { making phone calls. }\end{array}$} \\
\hline
\end{tabular}

As aging progresses, major changes occur in the body, which may result in CVS diseases. Strollo et al. (2014) reported that the prevalence of endocrine system diseases, particularly diabetes, increases with a less active life style, which occurs owing to physical and mental changes among the elderly. These diseases often develop into a more serious healthcare problem, particularly for those aged $\geq 65$ years (19). The incidence of musculoskeletal disorders also increases with age, thereby leading to a decrease in the physical functions of the elderly (20). Similar to other studies, this study found that the elderly primarily had CVS diseases (74.3\%), endocrine system diseases (40.7\%), and musculoskeletal disorders (35.1\%). Additional research by Catak et al. (21) detected the prevalence rate of CVS diseases to be $58.7 \%$, musculoskeletal disorders to be $35.4 \%$, and endocrine system diseases to be $20.5 \%$. Harugeri et al. (22) identified the prevalence rate of hypertension to be $41.5 \%$ and diabetes to be as $34 \%$. Zaveri et al. (23) reported the prevalence rate of CVS to be $59.9 \%$, respiratory system diseases to be $22.8 \%$, and diabetes to be as $12.3 \%$. Ellitt et al. (24) found the prevalence rate of circulatory system 


\begin{tabular}{|c|c|c|}
\hline Medication characteristics & $\mathbf{n}$ & $\%$ \\
\hline \multicolumn{3}{|l|}{ Number of daily medications } \\
\hline $1-2$ & 67 & 13.8 \\
\hline $3-4$ & 236 & 49.0 \\
\hline $5-6$ & 157 & 32.6 \\
\hline$\geq 7$ & 22 & 4.6 \\
\hline \multicolumn{3}{|l|}{ Route of drug administration } \\
\hline Oral & 478 & 99.2 \\
\hline Subcutaneous & 87 & 18.0 \\
\hline Respiratory & 76 & 15.8 \\
\hline Topical & 70 & 14.5 \\
\hline Intraocular & 60 & 12.4 \\
\hline Intramuscular & 34 & 7.0 \\
\hline \multicolumn{3}{|l|}{ Medication adverse effects } \\
\hline Yes & 192 & 39.8 \\
\hline No & 290 & 60.2 \\
\hline \multicolumn{3}{|l|}{ Complaints about medications* ( $=192)$} \\
\hline Gastrointestinal & 117 & 24.3 \\
\hline Skin & 34 & 7.1 \\
\hline Cerebrovascular & 33 & 6.8 \\
\hline Musculoskeletal & 20 & 4.1 \\
\hline Endocrine & 19 & 3.9 \\
\hline Cardiovascular, respiratory, psychiatric & 10 & 1.8 \\
\hline \multicolumn{3}{|l|}{ Difficulties with using medications* ( $n=482$ ) } \\
\hline Forgetting to take medications & 215 & 44.6 \\
\hline Obligation to use equivalent drugs & 186 & 38.6 \\
\hline Difficulty in administering medications & 178 & 36.5 \\
\hline Confusing drugs to be taken & 137 & 28.4 \\
\hline Inability to find medications at a pharmacy & 123 & 25.5 \\
\hline $\begin{array}{l}\text { Experiencing adverse effects when more than } \\
\text { one drug is taken }\end{array}$ & 121 & 25.1 \\
\hline Inability to take medications on time & 114 & 23.7 \\
\hline Difficulty in swallowing drugs & 84 & 17.4 \\
\hline Difficulty with dose adjustment & 77 & 16.0 \\
\hline Difficulty in continuing to take drugs as prescribed & 58 & 12.0 \\
\hline
\end{tabular}

diseases to be $54 \%$ and endocrine-metabolic system diseases to be $17.6 \%$, and Wimmer et al. (25) identified the prevalence rate of CVS diseases to be $82.2 \%$ and arthritis to be $36.8 \%(25)$.

The current study determined that $51.1 \%$ of the subjects had chronic diseases for $>16$ years. We first believed that the many years of illness may have occurred because of an inadequate access to health checkups as regular health examinations might provide earlier diagnoses and treatment. However, we realized that many elderly individuals are accustomed to liv- ing with chronic diseases. Furthermore, because chronic diseases are characterized by slow progression and long duration, the clinical manifestation and burden disproportionally affect the elderly (18).

The literature has also reported that the elderly experience difficulties in performing activities of daily living. These changes often occur owing to a decline in physical abilities, sensory losses, and chronic diseases (21, 26, 27). Yazıcı and Kalaycı (27) determined that the elderly with at least one chronic disease $(67.4 \%)$ and using five and more drugs (19.6\%) were semi- and completely dependent for activities of daily living such as taking a bath $(62.8 \%)$ and going to the bathroom $(52.9 \%)$ (27).

Studies also indicate that the elderly are prescribed many drugs to relieve symptoms of chronic diseases (28). This current study found that $49 \%$ of the subjects took 3-4 drugs daily, whereas $32.6 \%$ of them took 5-6 drugs on a daily basis. Rozenfeld et al. (29) reported that the average number of drugs used by the elderly was 3.7. Similar to our study, Arslan and Eser (30) found that 35\% of the elderly used 5-6 drugs daily, Solmaz and Akın (31) identified that $46.5 \%$ of the elderly used three and more drugs daily, and Catak et al. (21) found that $26.5 \%$ of the elderly used five and more drugs. Most of our study subjects (99.2\%) took their drugs orally. Wimmer et al. (25) also reported that the most common route of drug intake for the elderly was the oral route (98.2\%).

Adverse effects caused by medications are often observed among elderly patients (6). In this study, $60.2 \%$ of the subjects did not experience any adverse effects of the medications; however, $39.8 \%$ of them did experience adverse effects, and the most common ones were associated with GIS (24.3\%), skin $(7.1 \%)$, and the cerebrovascular system (6.8\%). Arslan and Eser (30) reported that $73.3 \%$ of the elderly did not have any adverse effects because of the drugs they used; however, $26.7 \%$ of them had stomach complaints as the drug adverse effect. Harugari et al. (28) reported that the most common adverse effects among the elderly using medications were gastrointestinal tract defects, bleeding and coagulation disorders, and CVS diseases (28). Camargo et al. (2006) reported that as the number of drugs used by the elderly increased, the prevalence of adverse effects also increased (32).

When elderly patients use more than one drug, it is particularly important for them to take their medication at the appointed times to ensure the treatment efficacy (33). Arslan and Eser (30) and Demirbag and Timur (34) revealed that $65 \%$ and $24 \%$ of the elderly, respectively, forgot to take their medications.

This study determined that the duration of chronic diseases was affected by sex and age. Corrao et al. (17) reported that women live longer and outnumber men. In contrast, older women develop more chronic diseases, and being female, 
Table 3. Chronic disease duration of the subjects according to sociodemographic characteristics ( $n=472$ )

\begin{tabular}{|c|c|c|c|c|c|c|}
\hline \multirow[b]{2}{*}{$\begin{array}{l}\text { Sociodemographic } \\
\text { characteristics }\end{array}$} & \multicolumn{6}{|c|}{ Disease duration } \\
\hline & $\begin{array}{l}1-5 \text { years } \\
n(\%)\end{array}$ & $\begin{array}{c}\text { 6-10 years } \\
n(\%)\end{array}$ & $\begin{array}{l}\text { 11-15 years } \\
\text { n (\%) }\end{array}$ & $\begin{array}{l}\geq 16 \text { years } \\
\quad n(\%)\end{array}$ & $\begin{array}{l}\text { Total } \\
\text { n (\%) }\end{array}$ & $\begin{array}{l}\chi^{2} \\
\mathbf{p}\end{array}$ \\
\hline \multicolumn{7}{|l|}{ Sex } \\
\hline Female & $16(47.1)$ & $48(65.8)$ & $79(63.7)$ & $105(43.6)$ & $248(52.5)$ & 19.504 \\
\hline Male & $18(52.9)$ & $25(34.3)$ & $45(36.3)$ & $136(56.4)$ & $224(47.5)$ & 0.000 \\
\hline \multicolumn{7}{|l|}{ Age } \\
\hline $65-74$ years & $21(61.8)$ & $55(75.3)$ & $72(58.1)$ & $103(42.7)$ & $251(53.2)$ & 36.964 \\
\hline $75-84$ years & $9(26.5)$ & $17(23.3)$ & $48(38.7)$ & $109(45.2)$ & $183(38.8)$ & 0.000 \\
\hline$\geq 85$ years & $4(11.8)$ & $1(1.4)$ & $4(3.2)$ & $29(12.0)$ & $38(8.1)$ & - \\
\hline \multicolumn{7}{|l|}{ Employment status } \\
\hline Retired & $14(41.2)$ & $25(34.3)$ & $30(24.2)$ & $50(20.8)$ & $119(25.2)$ & 10.372 \\
\hline Housewife & $20(58.8)$ & $48(65.8)$ & $94(75.8)$ & $191(79.3)$ & $353(74.8)$ & 0.016 \\
\hline \multicolumn{7}{|l|}{ Monthly income level } \\
\hline Income higher than expenses & $8(23.5)$ & $4(5.5)$ & $9(7.3)$ & $14(5.8)$ & $35(7.4)$ & 17.882 \\
\hline Income equal to expenses & $8(23.5)$ & $34(46.6)$ & $63(50.8)$ & 95 (39.4) & $200(42.4)$ & 0.007 \\
\hline Income lower than expenses & $18(52.9)$ & $35(48.0)$ & $52(41.9)$ & $132(54.8)$ & $237(50.2)$ & - \\
\hline \multicolumn{7}{|l|}{ Social security coverage } \\
\hline State retirement fund for civil servants & $25(73.5)$ & $33(45.2)$ & $47(37.9)$ & $112(46.5)$ & $217(46.0)$ & 56.161 \\
\hline $\begin{array}{l}\text { State retirement fund for artisans } \\
\text { and self-employed individuals }\end{array}$ & $6(17.7)$ & $17(23.3)$ & $32(25.8)$ & $39(16.2)$ & 94 (19.9) & 0.000 \\
\hline State retirement fund for workers/laborers & $1(2.9)$ & $23(31.5)$ & $41(33.1)$ & $53(22.0)$ & $118(25.0)$ & - \\
\hline Private insurance & $2(5.9)$ & - & $4(3.2)$ & $37(15.4)$ & $43(9.1)$ & - \\
\hline
\end{tabular}

older, and having a low socioeconomic level are associated with multimorbidity and an increased risk for hospitalization. Studies have reported that as an individual ages, the number of chronic diseases increases owing to decreased physical, psychological, and social abilities $(6,35,36)$. Majeed (37) found a correlation among chronic disease prevalence, sex, and age. Furthermore, the duration of chronic diseases of the elderly was affected by profession, monthly income level, and social security coverage. Regarding the employment status of the elderly, approximately $40 \%$ of females and $24.5 \%$ of males are unable to work (38). Majeed (37) also detected a correlation between chronic disease prevalence and profession. An individual's standard of living will most likely affect their health status. Lawlor et al. (39) reported that a low economic level reduced the ability of the elderly to cope with an illness and disease.

The current study indicated that age affected the number of medications taken daily. A study (40) reported that the ratio of drug use increases over time, and on an average, women aged 70 years take 3.8 drugs compared with men of the same age who take 3.5 drugs. Similar to our study, Kutsal et al. (41) demonstrated a significant difference between the number of medications taken daily and age. In addition, Heuberger et al. (42) demonstrated that the prevalence of polypharmacy among their subjects was $43.4 \%$; with $51.1 \%$ of them using five or more medications and $38.2 \%$ using et least two drugs on a daily basis. Another factor that affected daily drug use of the elderly was marital status. Similar to our study, Haider et al. (43) found a significant correlation between the number of medications taken daily and marital status.

The literature suggests that socioeconomic factors are closely associated with the health status and medication use by the elderly $(44,45)$. Our study found that educational level, social security coverage, and profession affected the number of medications taken daily, and Haider et al. (43) discovered a significant correlation between the number of medications taken daily by the elderly and their educational level. The same study also determined that the number of drugs taken by the elderly with a low educational level was 4.6 and that as their educational level increased, this number decreased. Hence, social security coverage was associated with medication use (43). Kim et al. (46) assessed predominately housewives and retirees and confirmed that social security coverage was associated with multiple medication use, and the elderly with this insurance were three times more likely to be associated with polypharmacy. Rosa et al. (47) suggested that retirees and housewives were almost eight times more likely to present with morbidities regarding drug-related problems.

Economic, political, and social changes in our society affect the family and the support they provide. In this study, the 
Table 4. Number of daily medications used of the study subjects according to sociodemographic characteristics ( $\mathrm{n}=482$ )

\begin{tabular}{|c|c|c|c|c|c|c|}
\hline \multirow[b]{2}{*}{$\begin{array}{l}\text { Sociodemographic } \\
\text { characteristics }\end{array}$} & \multicolumn{5}{|c|}{ Number of daily medications } & \multirow[b]{2}{*}{$\mathbf{p}$} \\
\hline & $\begin{array}{c}1-2 \\
n(\%)\end{array}$ & $\begin{array}{c}3-4 \\
n(\%)\end{array}$ & $\begin{array}{c}5-6 \\
n(\%)\end{array}$ & $\begin{array}{c}\geq 7 \\
\mathrm{n}(\%)\end{array}$ & $\begin{array}{l}\text { Total } \\
\text { n (\%) }\end{array}$ & \\
\hline \multicolumn{7}{|l|}{ Age } \\
\hline $65-74$ years & $46(68.7)$ & $138(58.5)$ & $64(40.8)$ & $7(31.8)$ & $255(52.9)$ & 25.188 \\
\hline $75-84$ years & $15(22.4)$ & $83(35.2)$ & $77(49.0)$ & $13(59.1)$ & $188(39.0)$ & 0.000 \\
\hline$\geq 85$ years & $6(9.0)$ & $15(6.4)$ & $16(10.2)$ & $2(9.1)$ & $39(8.1)$ & \\
\hline \multicolumn{7}{|l|}{ Marital status } \\
\hline Married & $35(52.2)$ & $133(56.4)$ & $71(45.2)$ & $13(59.1)$ & $252(52.3)$ & 21.475 \\
\hline Widow & $32(47.8)$ & $92(39.0)$ & $66(42.0)$ & $7(31.8)$ & $197(40.9)$ & 0.002 \\
\hline Divorced & - & $11(4.7)$ & $20(12.7)$ & $2(9.1)$ & $33(6.8)$ & - \\
\hline \multicolumn{7}{|l|}{ Education status } \\
\hline Illiterate & $5(7.5)$ & $32(13.6)$ & $14(8.9)$ & $4(18.2)$ & $55(11.4)$ & 31.339 \\
\hline Literate & $28(41.8)$ & $75(31.8)$ & $28(17.8)$ & $3(13.6)$ & $134(27.8)$ & 0.002 \\
\hline Primary school & $26(38.8)$ & $88(37.3)$ & $71(45.2)$ & $13(59.1)$ & $198(41.1)$ & - \\
\hline High school & $6(9.0)$ & $33(14.0)$ & $33(21.0)$ & $2(9.1)$ & $74(15.4)$ & - \\
\hline University & $2(3.0)$ & $8(3.4)$ & $11(7.0)$ & - & $21(4.4)$ & - \\
\hline \multicolumn{7}{|l|}{ Employment status } \\
\hline Retired & $39(58.2)$ & $67(28.4)$ & $18(11.5)$ & $3(13.6)$ & $127(26.3)$ & 55.306 \\
\hline Housewife & $28(41.8)$ & $169(71.6)$ & $139(88.5)$ & 19 (86.4) & $355(73.7)$ & 0.000 \\
\hline \multicolumn{7}{|l|}{ Social security coverage } \\
\hline State retirement fund for civil servants & $62(92.5)$ & $121(51.3)$ & $39(24.8)$ & $5(22.7)$ & $227(47.1)$ & 116.703 \\
\hline $\begin{array}{l}\text { State retirement fund for artisans and } \\
\text { self-employed individuals }\end{array}$ & $4(6.0)$ & $49(20.8)$ & $33(21.0)$ & $8(36.4)$ & $94(19.5)$ & 0.000 \\
\hline State retirement fund for workers/laborers & $1(1.5)$ & $51(21.6)$ & $59(37.6)$ & $7(31.8)$ & $118(24.5)$ & - \\
\hline Private insurance & - & $15(6.4)$ & $26(16.6)$ & $2(9.1)$ & $43(8.9)$ & - \\
\hline \multicolumn{7}{|l|}{ Person with whom the elderly lived } \\
\hline Alone & $12(17.9)$ & $23(9.7)$ & $9(5.7)$ & - & $44(9.1)$ & 29.281 \\
\hline With spouse & $19(28.4)$ & $69(29.2)$ & $23(14.6)$ & $7(31.8)$ & $118(24.5)$ & 0.001 \\
\hline With spouse and children & $13(19.4)$ & $64(27.1)$ & 47 (29.9) & $6(27.3)$ & $130(27.0)$ & - \\
\hline With family members & $23(34.3)$ & $80(33.9)$ & $78(49.7)$ & $9(40.9)$ & $190(39.4)$ & - \\
\hline
\end{tabular}

number of medications taken daily by the elderly was affected by the person with whom they lived. Ozdemir (48) stated that the elderly who were married or did not live with children demonstrated a more positive and compliant medication use behavior, which could be explained by the possibility that spouses often support each other when medications need to be taken and that children may not offer this same level of support.

\section{Study Limitations}

This study has some limitations. The study findings may be generalized only to this specific group; thus. more studies with larger Turkish sample populations are warranted. However, we believe that the study will be a valuable resource to relevant studies in the future because it provides data regarding the prevalence of chronic diseases and drug use among the elderly population in our country.

\section{Conclusion}

The study results revealed that $53.1 \%$ of the subjects were females, $52.9 \%$ belonged to the 65-74-year age group, and $52.3 \%$ were married. This study also found that chronic diseases were present among nearly all the elderly aged $\geq 65$ years. Thus, we can conclude that the prevalence of chronic diseases, particularly CVS diseases (74.3\%), endocrine system diseases $(40.7 \%)$, and musculoskeletal disorders $(35.1 \%)$, is high among the Turkish elderly population, with $51.1 \%$ having a chronic disease for $>16$ years and $74.5 \%$ experiencing difficulties in performing activities of daily living. Furthermore, nearly half of the subjects took three to four medications daily, and their most challenging aspect "forgetting to take their medications." Nearly all of them (99.2\%) took their medications orally, and $39.8 \%$ of them had health complaints owing to the drugs they used. Sex, age, profession, monthly 
income level, and social security status affected the duration of the chronic diseases of the elderly, whereas age, marital status, educational level, profession, social security coverage, and the people with whom they lived affected the number of medications they used daily.

The elderly should be monitored by means of protection of CVS diseases, endocrine system diseases, and musculoskeletal disorders, early diagnosis, chronic disease management, and drug efficacy and adverse effects by organizing training programs on aspects mentioned. Sociodemographic characteristics of the elderly in this training program should also be considered. In addition, studies comparing sociodemographic characteristics of the elderly with difficulties caused by chronic diseases and drug use need to be conducted.

We believe that the study results will increase the awareness regarding chronic disease and drug use among geriatric cases. At the same time, these study results may be a guide for chronic disease and drug management; for planning, implementing, and monitoring of healthcare services; and for preparing prevention programs with regard to the adverse effects of chronic diseases and drugs.

Ethics Committee Approval: Ethic committee approval was received for this study from the ethics committee of Karadeniz Technical University School of Medicine (2014/38).

Informed Consent: Written informed consent was obtained from each participant.

Peer-review: Externally peer-reviewed.

Author Contributions: Conception - D.S., S.H.; Design - D.S., S.H.; Supervision - D.S., S.H.; Funding - D.S.; Materials - D.S.; Data Collection and/or Processing - D.S.; Analysis and/or Interpretation - D.S., S.H.; Literature Review - D.S.; Writer - D.S., S.H.; Critical Review - D.S., S.H.

Conflict of interest: No conflict of interest was declared by the authors.

Financial Disclosure: The authors declared that this study has received no financial support.

\section{References}

1. TUIK Elderly Statistics (2016) Turkish Statistical Institute, Printing Division, Publication Number: 21520, Ankara. [homepage on the internet]. [cited 2016 June 06]. Available from: URL: http://www.tuik.gov.tr/PreHaberBultenleri. do?id=21520.

2. World Health Organization (2014). Global Status Report on Noncommunicable Diseases 2014, Burden: Mortality, Morbidity and Risk Factors. [homepage on the internet]. [cited 2016 June 08]. Available from: URL: http://www.who.int/nmh/publications/ncd_report2010/en.

3. Tiftik S, Kayıs A, Inanır I. Systemic disturbances, diseases and role of nursing in the elderly. Akat Geriatri 2012; 4: 1-11.
4. TUİK (2016) Ölüm Nedeni İstatistikleri, 2015, Publication Number: 21526, Ankara [homepage on the internet]. [cited 2016 June 06]. Avaible from: http://www.tuik.gov.tr/PreHaberBultenleri.do?id=21526.

5. Draper CA, Draper CE, Bresick GF. Alignment between chronic disease policy and practice: case study at a primary care facility. PLoS One 2014; 20: 1-8.

6. Unsal A, Demir G, Ozkan AC, Arslan GG. The prevalence chronic disease and drug use of the olders living in nursing home. ADU Tip Fakültesi Dergisi 2011; 12: 5-10.

7. Gulhan R. Rational drug use in elderly. Okmeydanı Tip Dergisi 2013; 29: 99-105. [CrossRef]

8. Marengoni A, Winblad B, Karp A, Fratiglioni L. Prevalence of chronic diseases and multimorbidity among the elderly population in Sweden. Am J Public Health 2008; 98: 1198-1200. [CrossRef]

9. Kim HA, Shin JY, Kim MH, Park BJ. Prevalence and predictors of polypharmacy among Korean Elderly. PLos ONE 2014; 9: 1-7. [CrossRef]

10. Ozer E, Ozdemir L. Rational drug usage in elderly and nurse's responsibilities. Hacettepe University Faculty of Health Sciences Nursing Journal 2009; 16: 42-51.

11. Veena DR, Padma L, Sapma P. Drug prescribing pattern in elderly patients in a teaching hospital. JDMS 2012; 1: 39-42.

12. Loya AM, González-Stuart A, Rivera JO. Use of prescription and over-the-counter medications and dietary supplements among older adults in the United States. JAMA 2008; 26: 42336.

13. Qato DM, Alexander GC, Johnson M, Conti RM, Schumm P, Lindau ST. Use of prescription and over the counter medications and dietary supplements among older adults in the united states. JAMA 2008; 300: 2867-12. [CrossRef]

14. Budnitz DS, Shehab N, Kegler SR, Richards CL. Medication use leading to emergency department visits for adverse drug events in older adults. Ann Intern Med 2007; 147: 755-765. [CrossRef]

15. Ahmad A, Mast MR, Nijpels G, Elders PJM, Dekker JM, Hugtenburg JG. Identification of drug-related problems of elderly patients discharged from hospital. Patient Preference and Adherence 2014; 8: 155-165.

16. Kaya $\mathrm{H}$. Patient education in health services and responsibilities of nurse: review. Turkiye Klinikleri J Nurs 2009; 1: 19-23.

17. Corrao S, Santalucia P, Argano C, Djade CD, Barone E, Tettamanti $\mathrm{M}$ et al. Gender-differences in disease distribution and outcome in hospitalized elderly: Data from the REPOSI study. Eur J Inter Med 2014; 25: 617-623. [CrossRef]

18. Feng L, Li P, Wang X,Hu Z, Ma Y, Tang Wet al. Distribution and determinants of non communicable diseases among elderly Uyghur ethnic group in Xinjiang. PLos ONE 2014; 9: 1-11. [CrossRef]

19. Strollo F, Guarino G, Marino G, Paolisso G, Gentile S. Different prevalence of metabolic control and chronic complication rate according to the time of referral to a diabetes care unit in the elderly. Acta Diabetol 2014; 51: 447-453. [CrossRef]

20. Erdil F, Bayraktar N. Yaşlı bireylerde kas-iskelet sorunlarına yönelik hemşirelik yaklaşımları. İÜFN Hem Derg 2010; 18: 106-113.

21. Catak B, Kılınç AS, Badıllıglu O, Sutlu S, Sofuoglu AE, Aslan D. Profile of elderly patients who use health services in their homes and in-home care. Turkish Journal of Public Health 2012; 10: 13-21. 
22. Harugeri A, Joseph H, Parthasarathi G, Ramesh M, Guido S. Potantially inappropriate medication use in elderly patients: A study of prevalence and predictors in two teaching hospitals. Journal of Postgradute Medicine 2010; 56: 186-191. [CrossRef]

23. Zaveri HG, Mansuri S, Patel VJ. Use of potentially inappropriate medicines in elderly: A prospective study in medicine outpatient department of a tertiary care teaching hospital. Indian J Pharmacol 2010; 42: 95-98. [CrossRef]

24. Ellitt GR, Engblom E, Aslani P, Westerlund T, Chen TF. Drug related problems after discharge from an Australian teaching hospital. Pharm World Sci 2010; 32: 622-630. [CrossRef]

25. Wimmer BC, Dent E, Visvanathan R, Wiese MD, Johnell $\mathrm{K}$, Chapman I et al. Polypharmacy and medication regimen complexity as factors associated with hospital discharge destination among older people: A prospective cohort study. Drugs \&Aging 2014; 31: 623-630. [CrossRef]

26. Dudak AH, Cakıl E, Aykut M, Cetinkaya F, Gunay O, Ozturk Y. Medico-social problems and affecting factors of life satisfaction in elderly living in Kayseri province. Turkish Journal of Geriatrics 2006; 9: 202-212.

27. Yazıcı SÖ, Kalaycı I. Yaşlı hastaların günlük yaşam aktivitelerinin değerlendirilmesi. Mühendislik Bilimleri ve Tasarım Dergisi 2015; 3: 385-390.

28. Harugeri A, Parthasarathi G, Ramesh M, Guido S, Basavanagowdappa $\mathrm{H}$. Frequency and nature of adverse drug reactions in elderly in-patients of two Indian medical college hospitals. J Postgrad Med 2011; 57: 189-95. [CrossRef]

29. Rozenfeld S, Fonseca MJM, Acurcio FA. Drug utilization and polypharmacy among the elderly: A survey in Rio de Janeiro City, Brazil. Pan Am J Public Health 2008; 23: 34-43. [CrossRef]

30. Arslan GG, Eser I. Self-medication compliance in elderly and nurses role. Ege University Hemsirelik Yuksekokulu Dergisi 2005; 21: 147-157.

31. Solmaz T, Akın B. Medication use and ability of selfmedication use in elderly living at home. Turkish Journal of Geriatrics 2009; 12: 72-81.

32. Camargo AL, Ferreira MBC, Heineck I. Adverse drug reactions: a cohort study in internal medicine units at a university hospital. Eur J Clin Pharmacol 2006; 62: 143-149. [CrossRef]

33. Murray MD, Morrow DG, Weiner M,Clark DO, Tu W, Deer $\mathrm{MM}$ et al. A conceptual framework to study medication adherence in older adults. Am J Geriatr Pharmacother 2004; 2: 36-43. [CrossRef]

34. Demirbag BC, Timur M. The knowledge, attitude and behavior related to using drugs reflected by the group of elderly. ASHD 2012; 11: 1-8.
35. Soyuer F, Soyuer A. Older adults and physical activity. Inonu University Tıp Fakültesi Dergisi 2008; 15: 219-224.

36. Mizokami F, Koide Y, Noro T, Furuta K. Polypharmacy with common diseases in hospitalized elderly patients The American Journal of Geriatric Pharmacotherapy 2012; 10: 123-128. [CrossRef]

37. Majeed AA. Prevalence of self reported chronic diseases in relation to sociodemographic characteristicswork place and complaint symptom: Epidemiological study among healthy workers in KurdistanIraq (ESHWKI). Journal of Chinese Clinical Medicine 2011; 6: 74-84.

38. Basara BB, Mollahaliloglu S, Pulgat E, Kavuncubası S. Gender and residency effects on elderly health in Turkey. Ageing Int 2014; 39: 55-67. [CrossRef]

39. Lawlor DA, Patel R, Ebrahim S. Association between falls in elderly women and chronic diseases and drug use: cross sectional study. BMJ 2003; 327: 712-715. [CrossRef]

40. Lernfelt B, Samuelsson O, Skoog I, Landahl S. Changes in drug treatment in the elderly between 1971 and 2000. Eur J Clin Pharmacol 2003; 59: 637-644. [CrossRef]

41. Kutsal YG, Barak A, Atalay A, Baydar T, Kucukoglu S, Tuncer $T$ et al. Polypharmacy in the elderly: A multicenter study. Journal of the American Medical Directors Association 2009; 10: 486-490. [CrossRef]

42. Heuberger RA, Caudell K. Polypharmacy and nutritional status in older adults: A cross-sectional study. Adis Data Information BV 2011; 28: 315-23. [CrossRef]

43. Haider SI, Johnell K, Thorslund M, Fastbom J. Analysis of the association between polypharmacy and socioeconomic position among elderly aged $>77$ years in Sweden. Clinical Therapeutics 2008; 30: 419-427. [CrossRef]

44. Jaspinder K, Sargun S and Kawaljit K. Impact of age on the prevalence of chronic diseases in geriatric population. ISCA 2014; 3: 79-85.

45. Mwangi J, Kulane A, Hoi LV. Chronic diseases among the elderly in a rural Vietnam: prevalence, associated socio-demographic factors and healthcare expenditures. 2015; 14: 2-8. [CrossRef]

46. Kim HA, Shin JY, Kim MH, Park BJ. Prevalence and predictors of polypharmacy among Korean elderly. PLoS ONE 2014; 9: 1-7. [CrossRef]

47. Rosa TE, Benicio MH, Latorre MR, Ramos LR. Determinant factors of functional status among the elderly. Rev Saude Publica 2003; 37: 40-48. [CrossRef]

48. Leyla Ozdemir. Drug compliance in the elderly and influencing factors. Akad Geriatri 2012; 4: 18-22. 